\title{
Efficient Direct Protocorm-Like Bodies Induction of Dwarf Dendrobium using Thidiazuron
}

\author{
Panjan SUJJARITTHURAKARN, Kamnoon KANCHANAPOOM* \\ Prince of Songkla University, Faculty of Science, Department of Biology, Hat Yai, Songkbla \\ 90112, Thailand; kamnoon_k@yahoo.co.th ( ${ }^{*}$ corresponding author)
}

\begin{abstract}
An efficient induction of protocorm-like bodies (PLBs) from seedlings of dwarf Dendrobium was accomplished in order to develop mass-scale propagation. The effect of $\mathrm{N}^{6}$-benzyladenine (BA) and thidiazuron (TDZ) on the in vitro induction of PLBs was studied. TDZ was found to be a more effective inducer of PLBs and their proliferation than BA. The highest percentage for the induction of PLBs (86\%) and the highest number of PLBs (3.6) per protocorm were observed after 9 weeks of culture in modified Murashige and Skoog (MS) liquid medium supplemented with $18 \mu \mathrm{M}$ TDZ.
\end{abstract}

Keywords: Dendrobium hybrid, direct embryogenesis, micropropagation, protocorm, seed culture

\section{Introduction}

Orchids are popular horticultural and ornamental plants mostly because of their exquisite flowers. In Thailand, orchids are very important commercial plants and produce an annual income for Thailand of 2 billion Baht (Rojanawong et al., 2006). Dendrobium orchids, that are the largest genus in the family Orchidaceae, have become a major cut flower crop for export. Dendrobiums are normally reproduced asexually by division of offshoots, but the multiplication rate is low (Martin and Madassery, 2006; Nasiruddin et al., 2003). Sexual propagation to produce complete plants through orchid seeds is difficult because their seeds are minute and have no endosperm. Consequently, they need symbiotic fungi in order to germinate (Anjum et al., 2006; Thomas and Michael, 2007). Dwarf Dendrobium (Dendrobium 'Queen Pink' x Dendrobium 'Phakbung'), a member in Dendrobium hybrids, is a sympodial epiphytic orchid, and it has small pseudobulbs. Also, its flowers have longevity and blooms many times a year. It is generally used as a flowering-potted for ornamental plants. In addition, it has potential commercial value as gifts, souvenirs, or decorations which are miniaturized orchid plantlets with flowers. Therefore, tissue culture has for many years played an important role as a means to propagate orchids and several in vitro cultural protocols have been developed in this genus (Arditti and Ernst, 1993; Chugh et al., 2009).

The production of orchid seedlings from seeds involves three successive phases: germination, formation of protocorms, and seedling development (Mitra et al., 1976). The development of protocorms from germinated seed and the subsequent induction of PLBs, from different tissues as explants has become a reliable method for breeding orchids.
Propagation by formation of PLBs is a preferred option because of the large number of PLBs that can be obtained within a short period of time. The need for mass propagation has led to the development of in vitro methods such as the propagation of large-scale PLBs using: shoot tips (Malabadi et al., 2005; Sheela et al., 2004), leaf segments (Martin and Madassery, 2006; Park et al., 2002a), protocorms (Sheelavanthmath et al., 2005; Teng et al., 2004), flower stalks (Chen and Chang, 2000; Chen et al., 2002), stem segments (Luo et al., 2008) and root tips (Manners et al., 2010; Park et al., 2003). PLBs can proliferate rapidly and can readily regenerate into complete plantlets, so they are also the most general target tissue for genetic transformation studies in orchids (Liau et al., 2003; Sreeramanan et al., 2008). Moreover, PLBs are well-differentiated tissues that are sometimes regarded as orchid embryos that can develop two distinct bipolar structures, namely, the shoot and root meristem. Thus, these structures are able to convert to plantlets easily when grown on plant growth regulator-free medium ( $\mathrm{Ng}$ and Saleh, 2011).

Thidiazuron (TDZ: N-phenyl-N'-1,2,3-thidiazol-5ylurea), a phenylurea derivative and a non-purine cytokinin compound, is not catabolized via cytokinin oxidase (Hare and Van, 1994; Kishor and Devi, 2009). Previously, TDZ was reported to be effective in the regeneration of a number of orchid species such as Doritaenopsis (Ernst, 1994), Phalaenopsis (Chen and Piluek, 1995), Cymbidium (Chang and Chang, 1998; Nayak et al., 1997), Oncidium (Chen et al., 1999; Chen and Chang, 2001), and Dendrobium (Roy et al., 2007). BA ( $\mathrm{N}^{6}$-benzyladenine) is an adenine-type cytokinin. The beneficial effect of BA has also been described for the regeneration of several orchids, including the genera Oncidium (Kalimuthu et al., 2007), Geodorum (Sheelavantmath et al., 2000), Vanda (Decruse 
et al., 2003), Dendrobium (Martin and Madassery, 2006; Nayak et al., 2002), Vanilla (Geetha and Shetty, 2000), and Cymbidium (Paek and Yeung, 1991; Teixeira da Silva et al., 2006). However, along with changing of plant materials, response of plant growth regulators (PGRs) is greatly changed. Thus, functions of the exogenous PGRs are quite different from orchid species to species. In this study, it has been described an efficient and rapid method for induction of PLBs from protocorms of a dwarf Dendrobium using TDZ.

\section{Materials and methods}

\section{Seed culture}

Healthy plants of dwarf Dendrobium were planted in pots and grown under greenhouse at Department of Biology, Prince of Songkla University, Hat Yai, Songkhla, Thailand. Flowers were hand pollinated and a pair of bipartite pollinia was picked and deposited on the stigma of a flower during pollination. The pollinated plants were maintained in the greenhouse. The 3-month-old mature and well-developed seedpods were collected for seed germination experiments. Seeds of mature seedpods were cultured immediately after collection. Seedpods were surface sterilized by immersion in $95 \%$ ethanol and flamed then they were dissected longitudinally and the seeds were cultured on MS (Murashige and Skoog, 1962) medium.

\section{Culture medium and conditions}

MS medium containing $3 \%(\mathrm{w} / \mathrm{v})$ sucrose, $8.2 \mathrm{~g} / \mathrm{L}$ agar, and $15 \%(\mathrm{v} / \mathrm{v})$ coconut water $(\mathrm{CW})$ was used throughout the experiments as the basal medium. The $\mathrm{pH}$ of the medium was adjusted to 5.5 prior to autoclaving at $121^{\circ} \mathrm{C}$ at 1 $\mathrm{kPa}$ for $20 \mathrm{~min}$. All cultures were incubated at $25 \pm 1^{\circ} \mathrm{C}$ under a 16/8 (day/night) photoperiod provided with white fluorescent tubes at an intensity of 1,960 lux.

\section{Induction of PLBs}

The 2-month-old green protocorms were then used for induction of PLBs by transferring to $40 \mathrm{~mL}$ of the basal MS liquid medium supplemented with different concentrations of BA $(4.4,8.8,13.2,17.6$ or $22 \mu \mathrm{M})$ and TDZ $(4.5,9,13.5,18$ or $22.5 \mu \mathrm{M})$ in $100 \mathrm{~mL}$ Erlenmeyer flasks on a rotary shaker at $120 \mathrm{rpm}$ for proliferation and multiplication.

\section{Plantlet regeneration and transplantation of plantlets}

PLBs were transferred to the basal MS medium for plantlet regeneration. Plantlets with three or four welldeveloped roots were taken out from the culture medium and washed thoroughly under running tap water to remove agar. They were acclimatized in pots containing wetted coconut husk. After hardening, the transplanted plantlets were grown in the greenhouse.

\section{Experimental design and data analysis}

Five protocorms were implanted per flask and subcultures of these protocorms were carried out every 3 weeks. Experiments were carried out in a completely randomized design and repeated twice with each treatment having twenty-five replicates. After 9 weeks of culture, explants were evaluated in terms of the percentage of PLBs formed and the number of PLBs per explant. The data were analyzed statistically using one-way analysis of variance (ANOVA). The mean values were compared using Duncan's multiple range test at $\mathrm{P} \leq 0.05$.

\section{Results}

Seed germination occurred after 2 weeks of culture. The germinating seeds increased in size, became swollen, and later turned green. Seeds grew into protocorms after 2 months (Fig. 1A). Subsequently, the protocorms developed into PLBs after 6 weeks of culture on the PLB induction media. Formation of PLBs occurred directly on the surface of protocorms in the growth regulator medium. The efficiency of protocorms producing PLBs was dependent on the types and concentrations of cytokinins in the medium. The highest percentage of forming PLBs (86\%) and the highest number of PLBs per explant (3.6) was found on modified MS medium supplemented with $18 \mu \mathrm{M}$ TDZ (Fig. 1B, Tab. 1). Of the various concentrations of $\mathrm{BA}$ tested, the best response was recorded for the medium containing $4.4 \mu \mathrm{M}$ BA, when $56 \%$ produced PLBs with an average of 0.9 PLBs per explant. TDZ was therefore more effective than $\mathrm{BA}$ in inducing formation of PLBs. Direct formation of PLBs was observed from protocorms without the intermediate formation of callus.

PLBs were transferred to the basal MS medium upon which they developed into shoots and roots in 6 weeks (Fig. 1C). The regenerated plantlets were then potted to wetted coconut husk and kept in greenhouse (Fig 1D). They grew well and developed into normal plants after 12 weeks of transplantation.

\section{Discussion}

The types and concentrations of PGRs play an important role in in vitro propagation of many orchid species (Arditti and Ernst, 1993). Differences in the induction rate for PLBs were observed between the treatments with TDZ and the BA. Comparatively, TDZ gave a superior response to BA for inducing PLBs in dwarf Dendrobium. TDZ has been previously used successfully to induce PLBs and the subsequent proliferation in Dendrobium 'Chiengmai Pink' (Chung et al., 2005), Vanda coerulea (Malabadi et al., 2004) and Dendrobium chrysotoxum Lindl (Roy et al., 2007). In this study, TDZ at a particular concentration strongly stimulated the formation of PLBs. In a simi- 

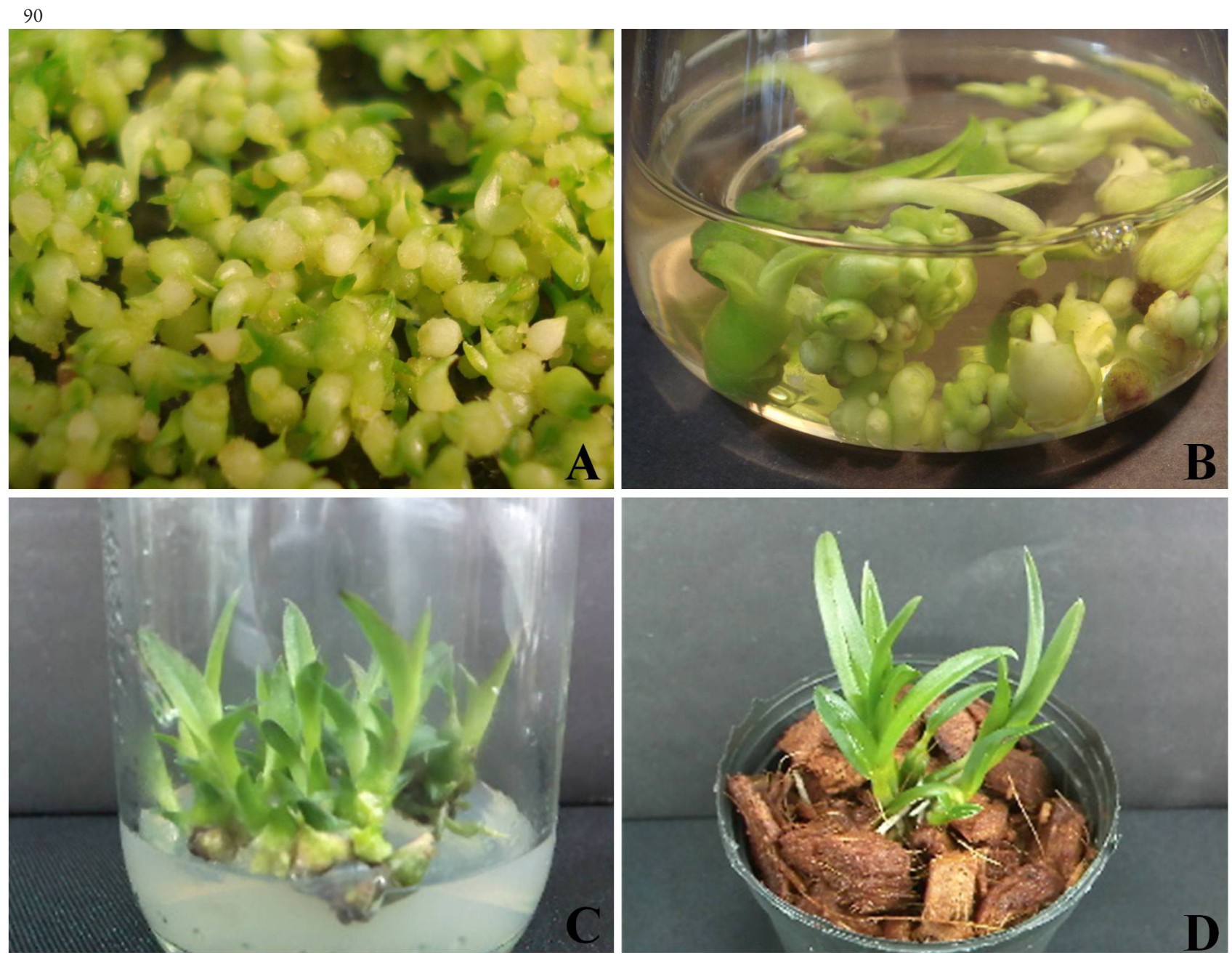

Fig. 1. (A) 2-month-old green protocorms. (B) PLBs development from protocorms after 9 weeks of culture in MS liquid medium with $18 \mu \mathrm{M}$ TDZ. (C) Plantlets developed on MS medium. (D) Acclimated plants

Tab. 1. Effects of TDZ and BA on the induction of PLBs from protocorms of dwarf Dendrobium after 9 weeks of culture

\begin{tabular}{|c|c|c|}
\hline $\begin{array}{c}\text { Cytokinin } \\
\text { concentration } \\
(\mu \mathrm{M})\end{array}$ & $\begin{array}{l}\text { PLB formation (\%) } \\
\quad(\text { Mean } \pm \text { SE) }\end{array}$ & $\begin{array}{c}\text { Number of PLBs } \\
\text { per explant } \\
\text { (Mean } \pm \text { SE) }\end{array}$ \\
\hline Control & $14.4 \pm 5.2^{\mathrm{c}}$ & $0.2 \pm 0.1^{\mathrm{c}}$ \\
\hline \multicolumn{3}{|c|}{ TDZ } \\
\hline 4.5 & $43.2 \pm 8.1^{\mathrm{bcd}}$ & $0.6 \pm 0.2^{b c}$ \\
\hline 9.0 & $30.4 \pm 7.3^{\mathrm{dc}}$ & $0.3 \pm 0.1^{\mathrm{c}}$ \\
\hline 13.5 & $32.0 \pm 6.8^{\mathrm{cdc}}$ & $0.4 \pm 0.1^{b c}$ \\
\hline 18 & $86.4 \pm 6.1^{a}$ & $3.6 \pm 0.5^{a}$ \\
\hline 22.5 & $25.6 \pm 8.0^{\mathrm{dc}}$ & $1.5 \pm 0.8^{b}$ \\
\hline \multicolumn{3}{|c|}{$\mathrm{BA}$} \\
\hline 4.4 & $56.0 \pm 8.5^{b}$ & $0.9 \pm 0.2^{b c}$ \\
\hline 8.8 & $41.6 \pm 8.6^{\mathrm{bcd}}$ & $0.8 \pm 0.3^{b c}$ \\
\hline 13.2 & $36.0 \pm 8.5^{\text {bcde }}$ & $0.5 \pm 0.1^{b c}$ \\
\hline 17.6 & $54.4 \pm 8.8^{\mathrm{bc}}$ & $0.9 \pm 0.2^{b c}$ \\
\hline 22 & $25.6 \pm 6.2^{\mathrm{de}}$ & $0.3 \pm 0.1^{\mathrm{c}}$ \\
\hline
\end{tabular}

Means within a column followed by the same letter are not significantly different by Duncan's multiple range test $(\mathrm{P} \leq 0.05)$ lar way, TDZ was found to be suitable for production of PLBs from thin leaf sections of a Doritaenopsis hybrid (Park et al., 2002b). This study also clearly shows that TDZ used alone was more effective than BA in PLBs induction and proliferation. This result is also in agreement with the observations in Epidendrum radicans (Chen et al., 2002), Doritaenopsis (Park et al., 2003), and Phalaenopsis (Kuo et al., 2005).

Morel (1960) was the first to report the shoot tip culture in orchids for mass propagation. Normally, plant regeneration and mass propagation from various types of explants have been achieved by four protocols. The first is adventitious bud induction through direct organogenesis. The second is protocorm induction which eventually develops into plantlets. The third is PLB regeneration through direct embryogenesis. The fourth is the transverse thin cell layers culture. According to these protocols, bud formation via organogenesis and direct PLBs formation through embryogenesis are used as the cultural conditions from the explants (Zhao et al., 2008). 
Regeneration of PLBs is comparable to the somatic embryogenesis pathway in orchids (Morel, 1974). Formation of PLBs can be classified into two types. The first is the direct formation of PLBs from protocorms, shoot tips, root tips, and stem segments through direct embryogenesis (Luo et al., 2008; Mayer et al., 2010; Naing et al., 2011). The second is indirect formation of PLBs from callus. (Hong et al., 2008; Huang and Chung, 2010; Ng and Saleh, 2011). In the present experiment, PLBs developed directly from the protocorms without callus formation. Similar result has been demonstrated for Aerides crispum (Sheelavanthmath et al., 2005). Lee and Phillips (1988) attributed this point as being of major importance because plants produced by direct regeneration will exhibit greater genetic stability than those produced by callus. Furthermore, regenerated plantlets, produced through the direct formation of PLB, produced fewer variants. Moreover, tissue cultures of orchids have not been focused on callus because of their slower growth rate and increased necrosis during culture (Zhao et al., 2008). In the present study, the proficiency for inducing PLBs from protocorms is in agreement with the finding of Sheelavanthmath $e t$ al. (2005) who illustrated that juvenile explants like protocorms and young leaves were important for the efficient induction of PLBs and the subsequent regeneration of plants in Aerides crispum.

\section{Conclusions}

The efficient induction of PLBs and their proliferation from protocorms of dwarf Dendrobium was achieved for large scale propagation. It was found that $18 \mu \mathrm{M} \mathrm{TDZ}$ was the optimum concentration for inducing PLBs.

\section{Acknowledgements}

This study was financially supported by Prince of Songkla University Graduate Studies Grant.

\section{References}

Anjum S, Zia M, Chaudhary MF (2006). Investigations of different strategies for high frequency regeneration of Dendrobium malones victory. Afr J Biotech 19:1738-1743.

Arditti J, Ernst R (1993). Micropropagation of orchid. John Wiley and Sons, New York.

Chang C, Chang WC (1998). Plant regeneration from callus culture of Cymbidium ensifolium var. misericors. Plant Cell Rep 17:251-255.

Chen Y, Piluek C (1995). Effect of thidiazuron and $\mathrm{N}^{6}-$ benzylaminopurine on shoot regeneration of Phalaenopsis. Plant Growth Reg 16:99-101.

Chen JT, Chang C, Chang WC (1999). Direct somatic embryogenesis on leaf explants of Oncidium 'Gower Ramsey' and subsequent plant regeneration. Plant Cell Rep19:143-149.

Chen JT, Chang WC (2000). Plant regeneration via embryo and shoot bud formation from flower-stalk explants of
Oncidium 'Sweet Sugar'. Plant Cell, Tiss Organ Cult 62:95100.

Chen JT, Chang WC (2001). Effects of auxins and cytokinins on direct somatic embryogenesis on leaf explants of Oncidium 'Gower Ramsey'. Plant Growth Reg 34:229-232.

Chen LR, Chen JT, Chang WC (2002). Efficient production of protocorm-like bodies and plant regeneration from flower stalk explants of the sympodial orchid Epidendrum radicans. In Vitro Cell Develop Biol Plant 38:441-445.

Chugh S, Guha S, Rao IU (2009). Micropropagation of orchids: A review on the potential of different explants. Sci Hortic 122:507-520.

Chung HH, Chen JT, Chang WC (2005). Cytokinins induce direct somatic embryogenesis of Dendrobium 'Chiengmai Pink' and subsequent plant. In Vitro Cell Develop Biol Plant 41:765-769.

Decruse SW, Gangaprasad A, Seeni S, Menon, VS (2003). Micropropagation and ecorestoration of $V$. spathulata, an exquisite orchid. Plant Cell, Tiss Organ Cult 72:199-202.

Ernst R (1994). Effect of thidiazuron on in vitro propagation of Phalaenopsis and Doritaenopsis (Orchidaceae). Plant Cell, Tiss Organ Cult 39:273-275.

Geetha S, Shetty SA (2000). In vitro propagation of Vanilla planifolia, a tropical orchid. Curr Sci79(6):886-889.

Hare PD, Van SJ (1994). Inhibitory effect of thidiazuron on the activity of cytokinin oxidase isolated from soybean callus. Plant Cell Physiol 35:1121-1125.

Hong PI, Chen JT, Chang, WC (2008). Plant regeneration via protocorm-like body formation and shoot multiplication from seed-derived callus of a maudiae type slipper orchid. Acta Physiol Plant 30:755-759.

Huang CH, Chung JP (2010). Efficient indirect induction of protocorm-like bodies and shoot proliferation using fieldgrown axillary buds of a Lycaste hybrid. Plant Cell, Tiss Organ Cult 106:31-38.

Kalimuthu K, Senthilkumar R, Vijayakumar S (2007). In vitro micropropagation of orchid, Oncidium sp ('Dancing Dolls'). Afr J Biotechn 6:1171-1174.

Kishor R, Devi S (2009). Induction of multiple shoots in a monopodial orchid hybrid (Aerides vandarum Reichb.f $X$ Vanda stangeana Reichb.f) using thidiazuron and analysis of their genetic stability. Plant Cell, Tissue Organ Cult 97:121-129.

Kuo HL, Chen JT, Chang WC (2005). Efficient plant regeneration through direct somatic embryogenesis from leaf explants of Phalaenopsis 'Little Steve'. In Vitro Cell Develop Biol Plant 41:453-456.

Lee SK, Phillips RL (1988). The chromosomal basis of somaclonal variation. Ann Review Plant Physiol Plant Molec Biol 39:413-437.

Liau CH, You SJ, Prasad V, Hsiao HH, Lu JC, Yang NS, Chan MT (2003). Agrobacterium tumefaciens-mediated transformation of an Oncidium orchid. Plant Cell Rep 21:993-998. 
92

Luo JP, Wang Y, Zha XQ, Huang L (2008). Micropropagation of Dendrobium densiflorum Lindl. ex Wall. through protocorm-like bodies: effects of plant growth regulators and lanthanoids. Plant Cell, Tiss Organ Cult 93:333-340.

Malabadi RB, Mulgund GS, Kallappa N (2004). Efficient regeneration of Vanda coerulea, an endangered orchid using thidiazuron. Plant Cell, Tiss Organ Cult 76:289-293.

MalabadiRB, MulgundGS, KallappaN(2005).Micropropagation of Dendrobium nobile from shoot tip sections. J Plant Physiol 162:473-478.

Manners V, Kumaria S, Tandon P (2010). Micropropagation of Vanda coerulea Griff ex Lindl.: A study of regeneration competence of roots in vitro. Proceedings of the International Conference on Environmental Engineering and Applications (ICEEA 2010), Singapore, 100-102 p.

Martin KP, Madassery J (2006). Rapid in vitro propagation of Dendrobium hybrids through direct shoot formation from foliar explants, and protocorm-like bodies. Sci Hortic 108:9599.

Mayer JLS, Stancato GC, Glória BAD (2010). Direct regeneration of protocorm-like bodies (PLBs) from leaf apices of Oncidium flexuosum Sims (Orchidaceae). Plant Cell, Tiss Organ Cult 103:411-416.

Mitra GC, Prasad RN, Choudhury AR (1976). Inorganic salts and differentiation of protocorm in seed callus of an orchid and correlated changes in its free amino acid content. Ind J Experiment Biol 14:350-351.

Morel GM (1960). Proding virus-free Cymbidium. Am Orchid Soc Bull 29:495-497.

Morel GM (1974). Clonal multiplication of orchids, p. 169122. In: Whitner CL (Ed.), The Orchids: Scientific Studies, Wiley Publisher.

Murashige T, Skoog F (1962). A revised medium for rapid growth and bioassays with tobacco tissue cultures. Physiol Plant 15:437-497.

Naing AH, Chung JD, Park IN, Lim KB (2011). Efficient plant regeneration of the endangered medicinal orchid, Coelogyne cristata using protocorm-like bodies. Acta Physiol Plant 33:659-666

Nasiruddin KM, Begum R, Yasmin S (2003). Protocorm like bodies and plantlet regeneration from Dendrobium formosum leaf callus. As J Plant Sci 13:955-957.

Nayak NR, Rath SP, Patnaik K (1997). In vitro propagation of three epiphytic orchids, Cymbidium aloifolium (L.) Sw., Dendrobium aphyllum (Roxb.) Fisch. and Dendrobium moschatum (Buch-Ham) Sw. through thidiazuron-induced high frequency shoot proliferation. Sci Hortic 71:243-250.

Nayak NR, Sahoo S, Patnaik S, Rath SP (2002). Establishment of thin cross section (TCS) culture method for rapid micropropagation of Cymbidium aloifolium (L.) Sw. and Dendrobium nobile Lindl. (Orchidaceae). Sci Hortic 94:107116.

$\mathrm{Ng} \mathrm{CY,} \mathrm{Saleh} \mathrm{NM} \mathrm{(2011).} \mathrm{In} \mathrm{vitro} \mathrm{propagation} \mathrm{of} \mathrm{Paphiopedilum}$ orchid through formation of protocorm-like bodies. Plant
Cell, Tiss Organ Cult 105:193-202.

Paek K Y, Yeung EC (1991). The effects of 1-naphthaleneacetic acid and $\mathrm{N}^{6}$-benzyladenine on the growth of Cymbidium forrestii rhizomes in vitro. Plant Cell, Tiss Organ Cult24:6571.

Park SY, Murthy HN, Paek KY (2002a). Rapid propagation of Phalaenopsis from floral stalk-derived leaves. In Vitro Cell Develop Biol Plant 38:168-172.

Park SY, Yeung EC, Chakrabarty D, Paek KY (2002b). An efficient direct induction of protocorm-like bodies from leaf subepidermal cells of Doritaenopsis hybrid using thin-section culture. Plant Cell Rep 21:46-51.

Park SY, Murthy HN, Paek KY (2003). Protocorm-like body induction and subsequent plant regeneration from root tip cultures of Doritaenopsis. Plant Sci 164:919-923.

Rojanawong T, Thepsithar C, Thongpukdee A (2006). Micropropagation of Phalaenopsis Cygnus 'Silky Moon' from leaf segments. Proceeding: $32^{\text {nd }}$ Congress on Science and Technology of Thailand, Thailand.

Roy J, Naha S, Majumdar M, Banerjee N (2007). Direct and callus-mediated protocorm-like body induction from shoottips of Dendrobium chrysotoxum Lindl. (Orchidaceae). Plant Cell, Tiss Organ Cult 90:31-39.

Sheela VL, Rajmohan K, Anita S, Sarada S (2004). Effect of growth regulators on development and multiplication of protocorm like bodies in Dendrobium cv 'Sonia. J Orchid Soc Ind 18:21-23.

Sheelavantmath SS, Murthy HN, Pyati AN, Kumar HGA, Ravishankar BV (2000). In vitro propagation of the endangered orchid, Geodorum densiflorum (Lam.) Schltr. through rhizome section culture. Plant Cell, Tiss Organ Cult 60:151-154.

Sheelavanthmath SS, Murthy HN, Hema BP, Hahn EJ, Paek, KY (2005). High frequency of protocorm like bodies (PLBs) induction and plant regeneration from protocorm and leaf sections of Aerides crispum. Sci Hortic 106:395-401.

Sreeramanan S, Vinod B, Sashi S, Xavier R (2008). Optimization of the transient-gusa gene transfer of Phalaenopsis violacea Orchid via Agrobacterium tumefaciens: an assessment of factors influencing the efficiency of gene transfer mechanisms. Adv Natural Appl Sci 2:77-88.

Teixeira da, Silva JA, Tanaka M (2006). Multiple regeneration pathways via thin cell layers in hybrid Cymbidium (Orchidaceae). J Plant Growth Reg 25:203-210.

Teng WL, Nicholson L, Teng MC (2004). Micropropagation of Spathoglottis plicata. Plant Cell Rep16:831-835.

Thomas TD, Michael A (2007). High-frequency plantlet regeneration and multiple shoot induction from cultured immature seeds of Rhynchostylis retusa Blume., an exquisite orchid. Plant Biotechn Rep 1:243-249.

Zhao P, Wu F, Feng FS, Wang WJ (2008). Protocorm-like body (PLB) formation and plant regeneration from the callus culture of Dendrobium candidum Wall ex Lindl. In Vitro Cell Develop Biol Plant 44:178-185. 